\title{
Improved Methods for the Diagnosis of African Trypanosomosis
}

\section{DE Rebeski/ ${ }^{+}$, EM Winger, B Rogovic, MM Robinson, JR Crowther*, RH Dwinger*}

Animal Production Unit, Food and Agriculture Organization/International Atomic Energy Agency Agriculture and Biotechnology Laboratory *Animal Production and Health Section, Joint Food and Agriculture Organization/International Atomic Energy Agency Division in Food and Agriculture, International Atomic Energy

Agency, P.O. Box 100, A-1400 Vienna, Austria

The diagnosis of trypanosomosis in animals with low parasitaemia is hampered by low diagnostic sensitivity of traditional detection methods. An immunodiagnostic method based on a direct sandwich enzyme-linked immunosorbent assay (ELISA), using monoclonal antibodies, has been examined in a number of African laboratories for its suitability for monitoring tsetse control and eradication programmes. Generally, the direct sandwich ELISAs for the detection of trypanosomal antigens in serum samples have proved to be unsatisfactory with respect to diagnostic sensitivity when compared with traditional parasitological methods such as the dark ground/phase contrast buffy-coat technique. Consequently, antigen-detection systems exploiting various other direct, indirect and sandwich ELISA systems and sets of reagents are being developed to improve diagnosis. In addition, an existing indirect ELISA for the detection of antibodies has been improved and is being evaluated in the field in order to detect cattle that are or have been recently infected with trypanosomes. Developments and advantages of other diagnostic techniques, such as dip-stick assay and tests based on the polymerase chain reaction are also considered.

Key words: ELISA - Trypanosoma congolense - Trypanosoma vivax - diagnosis - antibodies - antigen

During the past 20 years, immunoassay methods have been widely used for diagnosis of bovine trypanosomosis in the field (Nantulya 1990, Luckins 1992). These indirect techniques, detecting specific antibodies or antigens, offered a sufficiently simple, robust, and inexpensive tool which appeared accurate and reliable for diagnosing trypanosomosis.

The enzyme-linked immunosorbent assay (ELISA) used for antibody detection was based on the use of crude antigens derived from rodentpropagated trypanosomes (Luckins 1977) which resulted in batch to batch variation and unstable antigen preparations. Progress has been made in the ability to propagate trypanosomes in tissue culture under quality controlled conditions, e.g. Trypanosoma brucei (Greiner et al. 1997), but the stability of crude antigen preparations has not been improved.

Financial support: the Government of the Netherlands. Corresponding author. Fax: +43-1-2600.28222. E-Mail: D.Rebeski@iaea.org

Received 12 November 1998

Accepted 19 January 1999
For antigen detection, direct sandwich ELISAs (Nantulya \& Lindqvist 1989) based on monoclonal antibodies (Nantulya et al. 1987) were developed for use as a tool for monitoring tsetse control and eradication programmes in a number of African laboratories. The introduction of ELISAs for diagnostic purposes in African laboratories was facilitated by the establishment of the technique per $s e$, as well as through training of staff, data analysis and troubleshooting (IAEA 1993, 1997). However, lately major drawbacks have been identified since the assays were never fully standardized as recommended by Wright et al. (1993) and Jacobson (1998), and the true diagnostic proficiency of the assays was never established. These ELISAs were found to be unreliable for diagnosis of trypanosomosis (Rebeski et al. 1998a, Eisler 1998) when compared with traditional direct parasitological techniques such as the dark ground/phase contrast buffy-coat technique (BCT) (Murray et al. 1977).

A report is presented here, outlining recent developments and preliminary approaches at establishing immunoassay methods and molecular techniques for improving the diagnosis of trypanosomosis. The studies were made under the FAO/IAEA Animal Production and Health Subprogramme of the Joint FAO/IAEA Division of Nuclear Techniques in Food and Agriculture in 
support of the Coordinated Research Programme "Use of Immunoassay Methods for Improved Diagnosis of Trypanosomosis and Monitoring Tsetseand Trypanosomosis Control Programmes".

\section{MATERIALS AND METHODS}

Considerations for improving immunoassay methods to diagnose bovine trypanosomosis - With respect to the distribution and pathogenicity of bovine trypanosomosis, the current research work focused on $T$. congolense and T. vivax. For the improvement of diagnosis by means of ELISA, the use of standardized and stable reagents in assays and establishment of analytical and diagnostic sensitivity and specificity were recognized as crucial criteria. The technical aspects of ELISA, such as assay procedure, training, and troubleshooting proved successful in the past and needed less attention.

Several aspects merit consideration when examining antigen detection methods. These revolve around the nature of the antigen itself in a serum sample, the collection and processing of the sample and the biology of the trypanosome-host interaction. Reliable detection of trypanosomal antigen in the presence of antibody can be considered a problem since the quantity of circulating antigen is limited by the nature of sample tested (serum, plasma, red blood cells) or host's immune status. Depending on the latter, the concentration of detectable antigen could be low per se, or reduced by complexing with antibodies. In addition, reduced antigen detection in a given assay format may also be due to competition by antibody, e.g. for the same epitope as recognized by a monoclonal antibody in an indirect or direct competitive ELISA. The "sample" problem is being taken into account in our developments of indirect, competitive and sandwich ELISAs.

Standardization and stability assessment of reagents are being assured by the development of production methods under quality controlled conditions. Such developments will lead to the production of fully validated sets of reagents and test protocols to establish standardized methods with defined degrees of analytical and diagnostic specificity and sensitivity.

Biological reagents, chemicals and microtitre plates used for ELISAs - Bloodstream forms of $T$. congolense trypanosomes of stock CP-81, a derivative of the primary isolate Trans Mara I strain, and epimastigotes of T. vivax (IL3905) were used for routine standardized in-house bulk production of trypanosomes and antigen. In vitro propagation of $T$. congolense was carried out according to the method described by Hirumi and Hirumi (1990) and as modified by Rebeski et al. (1998b). Cul- tures of T. vivax epimastigote forms were initiated and expanded in absence of feeder cell layers in cell culture flasks $\left(75 \mathrm{~cm}^{2}\right.$ or $\left.150 \mathrm{~cm}^{2}\right)$ in a $\mathrm{CO}_{2}$ incubator with $5 \% \mathrm{CO}_{2}$ in air at $+27^{\circ} \mathrm{C}$. The axenic culture medium contained bathocuproine sulfonate and L-cysteine according to Zweygarth et al. (1991) but was modified using $10 \%$ rather than $20 \%$ of inactivated goat serum. Crude antigen preparations were obtained following ultrasonic cell disruption as described by Rebeski et al. (1998b). The use of both native and denatured antigen preparations were assessed by ELISA. Antigens were denatured $\left(\mathrm{AG}_{\mathrm{d}}\right)$ by detergent/heat treatment (Steindl et al. 1998). This treatment destroys conformational epitopes in trypanosomal samples. The robustness of the ELISA with respect to antigen stability was particularly addressed which is crucial to achieve an acceptable diagnostic proficiency following transfer of the methodology to laboratories in Africa.

Polyclonal immune sera have been produced in rabbits and guinea pigs against native antigen and AGd-preparations. The detergent/heat treatment of serum samples destroys antibodies and is known to disrupt any antigen/antibody complexes. The various sera and untreated and denatured antigens and samples, have been used in a variety of ELISA systems. Reference sera were obtained from cattle experimentally infected with $T$. congolense and $T$. vivax. Field sera were collected in various African countries and Austria. For ELISA cross-reactivity studies, serum was obtained from bovine blood samples which were positive for $T$. theileri and negative for trypanosomes pathogenic to ruminants. Reagents (conjugated anti-species antibodies) and chemicals (phosphate buffered saline buffer tablets, hydrogen peroxide substrate and 3,3' 5, 5'tetramethylbenzidine chromogen solutions, phosphoric acid, and skimmed milk powder) were purchased from commercial companies. Following comprehensive evaluation of ELISA microtitre plates of various brands with respect to identification of unacceptable background caused by nonspecific protein adsorption to the plastic surface, polystyrene immunoassay microtitre plates Immulon 1 (Dynex ${ }^{\circledR}$, USA) were used throughout.

\section{RESULTS AND DISCUSSION}

Diagnostic achievements and future research activities - A number of ELISA systems have been examined to measure antibody and antigen as shown in Table I. For these, both native and denatured field serum samples and concentrated antigen preparations have been examined. Such systems have provided successful assays and helped define reactivities of the antisera.

The laboratory-validated indirect ELISA for $T$. 
TABLE I

ELISA systems initially developed and examined for improved detection of trypanosomal antibody (AB) and/or antigen (AG)

\begin{tabular}{|c|c|c|c|c|c|c|c|}
\hline $\begin{array}{l}\text { ELISA } \\
\text { number }\end{array}$ & $\begin{array}{l}\text { ELISA } \\
\text { system }\end{array}$ & $\begin{array}{l}\text { Fresh coating } \\
\text { of reagents }\end{array}$ & Test sample & $\begin{array}{l}\text { Detecting AB } \\
\text { (unlabeled) }\end{array}$ & $\begin{array}{l}\text { Detecting AB } \\
\text { (enzyme- } \\
\text { labeled) }\end{array}$ & $\begin{array}{l}\text { Diagnostic } \\
\text { target }\end{array}$ & $\begin{array}{l}\text { Milestone } \\
12 / 1997\end{array}$ \\
\hline $\mathrm{I}-1$ & I-ELISA & $\begin{array}{l}\text { T. c. } \mathrm{AG}_{\mathrm{n}} \\
\text { or } \mathrm{AG}_{\mathrm{d}}\end{array}$ & $\begin{array}{l}\text { Serum, } \\
\text { blood on } \\
\text { filter paper }\end{array}$ & Not applied & $\begin{array}{l}\text { Commercial } \\
\text { product }\end{array}$ & T. c. $\mathrm{AB}$ & $\begin{array}{l}\text { Presently } \\
\text { under field } \\
\text { evaluation }\end{array}$ \\
\hline $\mathrm{I}-2$ & I-ELISA & $\begin{array}{l}\text { T. v. } \mathrm{AG}_{\mathrm{n}} \\
\text { or } \mathrm{AG}_{\mathrm{d}}\end{array}$ & Serum & Not applied & $\begin{array}{l}\text { Commercial } \\
\text { product }\end{array}$ & T. v. $\mathrm{AB}$ & Prototype \\
\hline $\mathrm{I}-3$ & D-C-ELISA & $\begin{array}{l}\text { T. c. } \mathrm{AG}_{\mathrm{n}} \\
\text { or } \mathrm{AG}_{\mathrm{d}}\end{array}$ & Serum & Not applied & $\begin{array}{l}\text { Polyclonal ABs } \\
\text { (bovine) }\end{array}$ & T. c. $\mathrm{AG} / \mathrm{AB}$ ? & Prototype \\
\hline $\mathrm{I}-4$ & I-C-ELISA & $\begin{array}{l}\text { T. c. } \mathrm{AG}_{\mathrm{n}} \\
\text { or } \mathrm{AG}_{\mathrm{d}}\end{array}$ & Serum & $\begin{array}{l}\text { Polyclonal } \\
\text { ABs (rabbit, } \\
\text { guinea pig) }\end{array}$ & $\begin{array}{l}\text { Commercial } \\
\text { product }\end{array}$ & T. c. AG/AB? & Prototype \\
\hline I-5 & I-C-ELISA & $\begin{array}{l}\text { T. v. } \mathrm{AG}_{\mathrm{n}} \\
\text { or } \mathrm{AG}_{\mathrm{d}}\end{array}$ & Serum & $\begin{array}{l}\text { Polyclonal } \\
\text { ABs (rabbit, } \\
\text { guinea pig) }\end{array}$ & $\begin{array}{l}\text { Commercial } \\
\text { product }\end{array}$ & T. v. $\mathrm{AG} / \mathrm{AB} ?$ & Prototype \\
\hline I-6 & I-Inh-ELISA & $\begin{array}{l}\text { T.c. } \mathrm{AG}_{\mathrm{n}} \\
\text { or } \mathrm{AG}_{\mathrm{d}}\end{array}$ & Serum & $\begin{array}{l}\text { Polyclonal } \\
\text { ABs (rabbit, } \\
\text { guinea pig) }\end{array}$ & $\begin{array}{l}\text { Commercial } \\
\text { product }\end{array}$ & T. c. AG/AB? & Prototype \\
\hline I-7 & I-S-ELISA & $\begin{array}{l}\text { Polyclonal } \\
\text { ABs (rabbit, } \\
\text { guinea pig) }\end{array}$ & Serum & $\begin{array}{l}\text { Polyclonal } \\
\text { ABs (rabbit, } \\
\text { guinea pig) }\end{array}$ & $\begin{array}{l}\text { Commercial } \\
\text { product }\end{array}$ & T. c. AG & Prototype \\
\hline
\end{tabular}

I-ELISA: indirect ELISA; D-C-ELISA: direct competitive ELISA; I-C-ELISA: indirect competitive ELISA; I-InhELISA: indirect inhibition ELISA; I-S-ELISA: indirect sandwich ELISA; $\mathrm{AG}_{\mathrm{n}}$ : native antigen; $\mathrm{AG}_{\mathrm{d}}$ : detergent/ heat treated antigen; T. c. : Trypanosoma congolense; T. v.: Trypanosoma vivax.

congolense antibody detection which exploits nondenatured antigen for coating immediately before ELISA testing (ELISA I-1 in Table I) is presently being evaluated under field conditions in 17 African laboratories. With regard to improving the assay robustness, the stability of $\mathrm{AG}_{\mathrm{d}}$ exploited in an indirect ELISA for T. congolense antibody detection was examined in 7 laboratories (ELISA F2 in Table II). Microplates were precoated with $\mathrm{AG}_{\mathrm{d}}$ and air-dried before shipment under uncontrolled conditions to laboratories in Africa. Results for $\mathrm{AG}_{\mathrm{d}}$-precoated plates were compared with those which were freshly coated with antigen immediately before ELISA testing. From the data obtained, it was evident that the robustness of the indirect $T$. congolense antibody ELISA was improved utilizing $\mathrm{AG}_{\mathrm{d}}$-precoated immunoassay plates (Rebeski et al. 1998b). Improved stability of $\mathrm{AG}_{\mathrm{d}}$ was found on precoated plates following storage at $+37^{\circ} \mathrm{C}$ for at least 7 weeks and shipment to laboratories in Africa under uncontrolled conditions. In addition, the proficiency and precision of the ELISA test utilizing $\mathrm{AG}_{\mathrm{d}}$-precoated plates were also improved. It was concluded that the use of $\mathrm{AG}_{\mathrm{d}}$-precoated plates contributes to an improved assay standardization and will also provide a measure of confidence with respect to laboratory proficiency by minimizing operator errors during coating. The stability of non-denatured crude antigen preparations following precoating is also being evaluated. Indirect ELISAs using microplates precoated with non-denatured antigen are presently being examined in this laboratory in terms of diagnostic sensitivity compared to indirect ELISAs exploiting $\mathrm{AG}_{\mathrm{d}}$ (ELISAs F-1, F-2, F-3 and F-4 in Table II).

The indirect competitive ELISAs involve the use of antigen-coated plates and interruption of the reaction of the various IgG fractions of guinea pig or rabbit antisera with this antigen. Use of native antigen-coated plates and antisera produced against the antigen, indicate that both antigen and antibody can be measured with high specificity and analytical sensitivity (ELISAs I-4 and I-5 in Table I).

The use of plates coated with denatured antigen and subsequent addition of rabbit or guinea pig antisera with denatured samples promises to be a method to determine only the antigen content 
TABLE II

Future ELISA systems to be assessed for improved detection of trypanosomal antibody (AB) and antigen (AG)

\begin{tabular}{|c|c|c|c|c|c|c|c|c|}
\hline $\begin{array}{l}\text { ELISA } \\
\text { number }\end{array}$ & $\begin{array}{l}\text { ELISA } \\
\text { system }\end{array}$ & $\begin{array}{l}\text { Coating } \\
\text { conditions }\end{array}$ & $\begin{array}{l}\text { Serum sample } \\
\text { (detergent/ } \\
\text { heat-treatment) }\end{array}$ & $\begin{array}{l}\text { Diagnostic } \\
\text { target }\end{array}$ & $\begin{array}{l}\text { Milestone } \\
06 / 1998\end{array}$ & $\begin{array}{l}\text { Milestone } \\
09 / 1998\end{array}$ & $\begin{array}{l}\text { Milestone } \\
03 / 1999\end{array}$ & $\begin{array}{l}\text { Milestone } \\
06 / 1999\end{array}$ \\
\hline F-1 & I-ELISA & $\mathrm{AG}_{\mathrm{n}}$ precoating & No & T. c. AB & Prototype & F-E & & \\
\hline F-2 & I-ELISA & $\mathrm{AG}_{\mathrm{d}}$ precoating & No & T. c. $\mathrm{AB}$ & Prototype & F-E & & \\
\hline F-3 & I-ELISA & $\mathrm{AG}_{\mathrm{n}}$ precoating & No & T. v. $\mathrm{AB}$ & Prototype & F-E & & \\
\hline F-4 & I-ELISA & $\mathrm{AG}_{\mathrm{d}}$ precoating & No & T. v. $\mathrm{AB}$ & Prototype & F-E & & \\
\hline F-5 & I-C-ELISA & $\mathrm{AG}_{\mathrm{d}}$ precoating & Yes & T. c. $\mathrm{AG}_{\mathrm{d}}$ & Prototype & F-E & & \\
\hline F-6 & I-C-ELISA & $\mathrm{AG}_{\mathrm{d}}$ precoating & Yes & T. v. $\mathrm{AG}_{\mathrm{d}}$ & & Prototype & F-E & \\
\hline F-7 & I-S-ELISA & fresh $\mathrm{AB}$ coating & Yes & T. c. $\mathrm{AG}_{\mathrm{d}}$ & Prototype & & F-E & $\begin{array}{l}\text { Dip - stick } \\
\text { prototype }\end{array}$ \\
\hline F-8 & I-S-ELISA & fresh $\mathrm{AB}$ coating & Yes & T. v. $\mathrm{AG}_{\mathrm{d}}$ & & Prototype & F-E & $\begin{array}{l}\text { Dip - stick } \\
\text { prototype }\end{array}$ \\
\hline
\end{tabular}

I-ELISA: indirect ELISA; I-C-ELISA: indirect competitive ELISA; I-S-ELISA: indirect sandwich ELISA; F-E: field evaluation; $\mathrm{AG}_{\mathrm{n}}$ : native antigen; $\mathrm{AG}_{\mathrm{d}}$ : detergent/heat treated antigen; T. c. : Trypanosoma congolense; T. v.: Trypanosoma vivax.

of samples (ELISAs F-5 and F-6 in Table II).

The sandwich ELISAs are based on combinations of rabbit or guinea pig capture and detecting antibodies with the appropriate anti-species conjugate. For $T$. congolense, a prototype assay (ELISA I-7 in Table I) has been developed successfully to detect trypanosomal antigen preparations. Further analysis of field samples is necessary in order to determine the actual levels of antigen present. This study also involves examination of the compartmentalization of antigen in samples, e.g. whether the trypanosomal antigens are associated with the red blood cells which are discarded when serum is taken for analysis. Here the use of polymerase chain reaction technique will be essential to evaluate the distribution of antigen in the various blood components. The reagents defined in these sandwich ELISAs (ELISAs F-7 and F-8 in Table II) will be adapted for development. The use of the antisera raised against $A_{\mathrm{d}}$ is also being investigated in terms of specificity with native and denatured samples.

Those reagents which prove suitable for antigen detection when exploited in an indirect sandwich ELISA system will also be of benefit in the development of a dip-stick assay for use in the field.

In conclusion, various ELISA systems have been constructed exploiting reagents for detection of antibodies and antigens derived from $T$. congolense and T. vivax trypanosomes. By means of laboratory and field validation studies, defined ELISA systems will be further assessed for their capacity to improve diagnosis of African trypanosomosis. Reagents, which prove successful in ELISA will be adapted for application in dip-stick technology.

\section{ACKNOWLEDGEMENTS}

To the technical assistance of Prof. H-J Bürger and Dr H Okoro, Faculty of Veterinary Medicine, JustusLiebig University, Giessen, Germany, Prof. P Büscher, Institute of Tropical Medicine, Antwerp, Belgium, Dr RA Masake and Mr JT Njuguna, International Livestock Research Institute, Nairobi, Kenya, Dr O Diall and Mr Y Sonogo, Laboratoire Central Vétérinaire, Bamako, Mali, Dr R Mattioli, International Trypanotolerance Center, Banjul, The Gambia, and Dr R Kaminsky and Mrs C Schmid, Swiss Tropical Institute, Basel, Switzerland. To Prof. P Holmes and Dr MC Eisler, Glasgow University Veterinary School, UK, for contribution to this study.

\section{REFERENCES}

Eisler MC 1998. Sensitivity and specificity of antigencapture ELISAs for diagnosis of Trypanosoma congolense and Trypanosoma vivax infections in cattle. Vet Parasitol 79: 187-201.

Greiner M, Kumar S, Kyeswa C 1997. Evaluation and comparison of antibody ELISAs for serodiagnosis of bovine trypanosomosis. Vet Parasitol 73: 97-205.

Hirumi H, Hirumi K 1990. In vitro cultivation of Trypanosoma congolense bloodstream forms in the absence of feeder cell layers. Parasitology 102: 225236.

IAEA 1993. Improving the diagnosis and control of trypanosomiasis and other vector-borne diseases of African livestock using immunoassay methods. Vienna, IAEA-TECDOC 707, $174 \mathrm{pp}$.

IAEA 1997. Application of an immunoassay method to 
improve the diagnosis and control of African trypanosomosis, Vienna, IAEA-TECDOC 925, $116 \mathrm{pp}$.

Jacobson RH 1998. Validation of serological assays for diagnosis of infectious diseases. Rev Sci Tech Off Int Epiz 17: 469-486.

Luckins AG 1977. Detection of antibodies in trypanosome-infected cattle by means of a microplate enzyme-linked immunosorbent assay. Trop Anim Hlth Prod 9: 53-62.

Luckins AG 1992. Methods for diagnosis of trypanosomiasis in livestock. World Animal Review 70/71: 1520.

Murray M, Murray PK, McIntyre WIM 1977. An improved technique for the diagnosis of African trypanosomiasis. Trans $R$ Soc Trop Med Hyg 71: 325326.

Nantulya VM 1990. Trypanosomiasis in domestic animals: the problems of diagnosis. Rev Sci Tech Off Int Epiz 9: 357-367.

Nantulya VM, Lindqvist KJ 1989. Antigen-detection enzyme immunoassays for the diagnosis of Trypanosoma vivax, $T$. congolense and $T$. bruce infections in cattle. Trop Med Parasitol 40: 267-272.

Nantulya VM, Musoke AJ, Rurangirwa FR, Saigar N, Minja SH 1987. Monoclonal antibodies that distinguish Trypanosoma congolense, T. vivax and $T$. brucei. Parasite Immunol 9: 421-431.

Rebeski DE, Winger EM, Dwinger RH 1998a. Perfor- mance of a direct sandwich enzyme linked immunosorbent assay for detection of trypanosomal antigens. Proceedings of the Workshop "Antigen ELISAs for Trypanosomes. Evaluation of the Performance". International Livestock Research Institute, Nairobi, Kenya, December 1996 (in press).

Rebeski DE, Winger EM, Lelenta M, Colling A, Robinson MM, Ndamkou Ndamkou C, Dwinger RH, Crowther JR 1998b. Use of denatured antigen on precoated microtitre plates for the detection of antibodies against Trypanosoma congolense by indirect enzyme-linked immunosorbent assay. Proceedings of the 9th Conference of the Association of Institutions of Tropical Veterinary Medicine, Harare, Zimbabwe, September 1998 (in press).

Steindl F, Armbruster C, Pierer K, Purtscher M, Katinger HWD 1998. A simple and robust method for the complete dissociation of HIV-1 p24 and other antigens from immune complexes in serum and plasma samples. J Immunol Methods 217: 143-151.

Wright PF, Nilsson E, Van Rooij EMA, Lelenta M, Jeggo MH 1993. Standardisation and validation of enzymelinked immunosorbent assay techniques for the detection of antibody in infectious disease diagnosis. Rev Sci Tech Off Int Epiz 12: 435-450.

Zweygarth E, Gray MA, Kaminsky R 1991. Axenic in vitro cultivation of Trypanosoma vivax trypomastigote forms. Trop Med Parasitol 42: 45-48. 
254

Improved Methods for the Diagnosis of African Trypanosomosis - DE Rebeski et al. 